\title{
Community Participation in Crime Prevention: Informal Social Control Practices in Site B, Khayelitsha Township
}

\author{
Jean-Claude Manaliyo \\ Community Development Resource Association, South Africa \\ Jean-Claude@cdra.org.za \\ Paul-Francois Muzindutsi \\ School of Economic Sciences \\ North-West University, Vanderbijpark, Republic of South Africa \\ muzindutsi@gmail.com
}

\section{Doi:10.5901/mjss.2013.v4n3p121}

\begin{abstract}
The role of informal social controls and their sanctions are still given little attention in crime prevention field. Some people still regard fighting and preventing crime as the work of the government and its agencies. This paper provides insight into the extent to which residents of Site B in Khayelitsha township take initiative to fight and prevent criminal activities in their area using informal social controls. Qualitative analysis was used to analyse the data collected from various categories of participants including ordinary residents, community police officers, community leaders and representatives of anti-crime organisations. Results indicate that the residents are reluctant to sanction offenders informally as a result of a high level of individualism among the residents. Some residents do not practise informal social controls because they fear to be arrested for sanctioning criminals and other offenders. This suggests that informal social controls conflict with formal sanctions rather than supporting and supplementing each other. However, individualism and lack of solidarity among residents of Site $B$ were found to be the major cause of weak informal social controls.
\end{abstract}

Keywords: Community participation, crime prevention, formal controls, informal controls

\section{Introduction}

As crime continues to devastate many people's lives and properties in South Africa, the government becomes a scapegoat. The government, particularly its whole criminal justice system is being pointed fingers for failing to control and maintain security to ensure every South African lives in a safe environment. The South African government considers formal sanctions as a central deterrent to crime and other deviant behaviours but the are failing to deter crime. Rather, some components of the criminal justice system are allegedly to be ineffective and inefficient (Faull, 2011). Criminals are often not arrested, and some of those arrested are released on bail without being prosecuted and many crime cases go undetected (Singh, 2005). In addition, many crime victims withdraw their cases before they go on trial because they have lost faith in the criminal justice system and due to delays in the criminal courts (Schönteich, 1999, Faull, 2011).

Demographically, most crimes in South Africa are committed by teenagers and young adults who are supposed to be controlled and guided by their parents. Lack of parental guidance is one of the factors which contribute to high crime rates in South Africa (Dissel, 1997; de Wet, 2003; Nleya \&Thompson, 2009). In some communities, youths have normalised illegitimate activities to acquire accolade or status (Pelser, 2008), and these activities seem to be accepted. A study conducted in 2008 by the Centre for Justice and Crime Prevention in 245 schools in South Africa also shows that violence is legitimated as a form of solving conflict by most learners (Mampane \& Bouwer, 2011).

Youth crime is a common problem across the world but young South Africans start committing crime when are younger. The existing literature indicates that youth at risk of pursuing criminal activities are aged between 15-25 years whilst the majority (43.5\%) of youth criminals in South Africa are aged between 10-15 years and $35.9 \%$ youth criminals are between 16-18 years old (Pelser, 2008). A study conducted in 2002 in South Africa shows that $36 \%$ of all sentenced prisoners were young people, and $53 \%$ of all awaiting trial prisoners were young people under 26 years (Palmary \& Moat, 2002). This high involvement of young people in criminal activities mirrors the ineffectiveness of the South African criminal justice system on one hand, and the weakness of informal social controls on the other hand. Some areas in the 
country especially townships, which are predominantly occupied by Black Africans are described as 'no-go' areas or 'warzone' (Mampane \& Bouwer, 2011). In South Africa, the term township or location usually refers to the often underdeveloped urban living areas that, from the late 19th century until the end of apartheid, were reserved for nonwhites, principally Black Africans and Coloureds (Estelle, 2003). Most of these townships were built on peripheries of towns and cities far from white occupied areas. The prevalence of crime in townships make people living in the areas be more at risk of being crime and violence victims (Møller, 2005).

The major challenge for the South African government is to mobilise communities to participate in fighting crime, especially in townships. Many South Africans are still seeing controlling and preventing crime as the responsibility of the government alone as they have no role to play. Based on the assumption that community members know their place better than anyone else (Liebermann \& Coulson, 2004), ordinary South Africans are to take the first step to fight and control crime in their communities using informal social controls. Crimes are committed on daily basis but community residents take no action other than waiting for formal controls which are allegedly to be weak and ineffective (Schönteich, 1999; Singh, 2005). The fact that criminals live within communities and are often known by community members, it is important to interrogate the role of community residents in preventing and fighting crime in their areas. Thus, the objective of this paper is to investigate how the informal social controls are used as a tool for fighting and preventing criminal activities in Site B, which is a section of Khayelitsha township in Cape Town.

\section{Conceptualising crime and informal social controls}

Crime has been consistently linked to social structures. Numerous investigations show that crime rates in communities are strongly correlated to the extent to which the communities are socially disorganised or organised (Sampson \& Groves, 1989; Saegert \& Winkel, 2004; Weijters, Scheepers \& Gerris, 2009). These investigations are evidently built on the work of Shaw and McKay (Shaw \& McKay, 1942, p. 436-441; Sampson \& Groves, 1989) who pioneered to link crime to social settings. In their work, Shaw and McKay developed social disorganisation theory which hypothesises that disorganised communities experience high crime rates whilst organised communities experience low crime rates.

Related to the theory of social disorganisation, crime rates are high in disorganised communities because social disorganisation erodes social bonds and increases social disruption in the communities, neighbourhoods, families, and even in the local based organisations including churches (Brewer, Lockhart \& Rogers, 1998). As a result of disorganisation, the communities lack common values and social cohesion which are driving forces for the community residents to control crime and maintain security collectively (Kawachi, Kennedy, \& Wilkinson, 1999; Steyn, de Beer \& Fouché, 2009). In this context, social disorganisation is defined as the inability of community residents to realise their common values and maintain effective social controls (Sampson \& Groves, 1989).

Controlling crime is done using either formal controls or informal controls and these controls are differentiated depending on people who administer the controls. Formal controls are deliberately organised and administered by governments to control crime through police and other components of the criminal justice system by sanctioning offenders formally. On other hand social informal controls, which are the main focus of this paper, are imposed and administered by ordinary citizens without external influences; and offenders are informally sanctioned based on shared values in the community. Informal social controls "emerge as products of role relationships established for other purposes" (Kornhauser, 1978, p. 24). In fact, the role of informal social controls may not even be noticed to the fact that they are part and parcel of cultural values and norms of communities. Informal social controls, however, work effectively when community residents are willing to participate in solving their local crime problems. When a community has strong and effective informal social controls crime rates are often low because the informal social controls act as an important mediator between neighbourhood residents and crime (Silver \& Miller, 2004).

Informal social controls use sanctions such as shame, condemnation, corporal punishment, isolation, and other detrimental consequences convicted offenders suffer which are not formally specified by law or pronounced by the judge in the disposition (Benson, 1989). These sanctions have a role to play in preventing and deterring criminal activities especially when imposed by family members, friends and neighbours. Empirical evidence in a social survey carried out by the British government on the consequence of arrest found that the majority of people do not consider the punishment associated with arrest as the most important consequence of arrest. Rather, they see informal sanctions such as shame, a tarnished reputation and a negative change in their relationship with family members and friends, as the most important consequence of arrest (Zimring \& Hawkins, 1973).

In the absence of informal social sanctions, crimes and other non-conforming activities are learnt, reinforced and even be normalised in the community because formal sanctions do not work effectively without being paired by informal 
social sanctions. Many people may see formal sanctions as the right tools for deterring crime and other deviant behaviours but studies show that formal sanctions and other external institutions do not work effectively within disorganised communities (Bishop, 1984; Fagan \& Meares, 2008; Jiang \& Lambert, 2009). In fact, informal social sanctions are stronger and more reliable deterrents than formal sanctions. Informal social sanctions can work effectively at their own without involving formal sanctions such as incarceration whilst formal sanctions work well when they are supported by informal sanctions.

The effectiveness of informal social sanctions depends on different factors including low economic status, ethnic heterogeneity, residential mobility, and family disruption (Sampson \& Groves, 1989). These factors erode the ability and willingness of community residents to practise informal social controls. Thus, community residents work individually rather than collectively to deter and control criminal behaviours. Residential mobility with a high influx of new-comers for example, acts as a barrier to the development of extensive friendship, kinship, trust, network, and collaboration (Sampson \& Groves, 1989). These features of social capital are ingredients of social cohesion which is also a component of social bond and unity. When a community experiences high quality of social capital, its residents are able to control teenage peer groups and other offenders.

Social capital reflects the ability of community residents to achieve common benefits in the sense that all residents share the same actions, motivations, and expected outcomes. It is in this sense that social capital is referred to as a property of groups (Saegert \& Winkel, 2004). Social capital is centred on mutual trust, pattern of reciprocity, shared norms and identity (Flora et al., 1997). Communities with higher social capital are more united and work as a team to solve their local problems including crime and other deviant behaviours. Components of social capital such as mutual trust, communalism, reciprocity, and sharing social values enable residents to network and share crime-related information. Ostrom (2000) suggests that social capital provides insight into how individuals deal with problems of collective action. In the same context, Putnam (2000:308) shows that crime rates are high in disorganised communities where there is low social capital.

Sharing information related to crime among community residents reciprocally and freely is crucial to sanction offenders. The effective flow of information, however, is possible if community residents are well-networked among themselves. This is more likely to happen in well-organised communities where residents are homogeneous and their mobility is limited. The limited mobility in a community enables community residents to know, interact and connect to each other very well and this allows information to flow freely (Saegert \& Winkel, 2004). Examples of social network members could be family members, business associates, church members, school children, and sports club members.

\section{Research methodology}

This study was conducted in Site B in Khayelitsha, which the biggest township in Cape Town. Site B was selected because is regarded as one of the crime 'hotspot' areas in Khayelitsha (City of Cape Town, 2009). The study involved 45 participants of different roles and responsibilities in the community. The participants include ordinary citizens, community leaders (ward councillors and street committees) and representatives of anti-crime organisations operating in Site B. These organisations include: Khayelitsha Development Forum (KDF), Khayelitsha Security and Safety Forum, South African National Civic Organisation (SANCO), Community Policing Forum (CPF), and the South African Police Service (SAPS). Purposive sampling was employed in this study because it is assumed that individuals chosen for the study would be those who will provide most valuable information (Guarte \& Barrios, 2006). This sampling method gave the researchers the flexibility and opportunity to select participants based on their experience and quality of information they possess.

Data of the study was collected in October 2011 using in-depth face-to-face interviews to allow the researchers to probe and deeply understand the extent to which residents of Site B practise informal social sanctions to fight and prevent crime and other non-conforming behaviours. Explanation regarding the objectives and purpose of the study was given to all participants before interviews taking place and participants were informed that they could withdraw from the interviews at any stage. Furthermore, the assurance of confidentiality and anonymity was given to the participants. All interviews were recorded, and then transcribed into word-for-word transcripts which were printed out to allow the researchers to read them and easily understand and identify impressive points in the texts.

To ensure reliability and trustworthiness of the results, the researchers reviewed the research questions which were to be answered in the data analysis. Then each question was linked to every individual's response in order to identify consistencies and differences. After bringing all the data of each question together, the researchers identified categories and themes and labelled them. Finally, patterns and connections within and between categories were 
identified because such connections were important in understanding and explaining effects and the relationship within and between themes. The researchers interpreted data to provide meanings which may be understood by readers.

\section{Results and Discussion}

\subsection{Individualism: a root cause of ineffective informal social controls in Site B}

The contribution of informal social controls to fighting crime and preventing potential crime in Site B is at minimal level. Residents are reluctant to sanction teenagers and other offenders informally. In the interviews, all participants including the police officers blamed parents for not being responsible in terms of controlling and guiding their children. One participant argued that parents and other community members are no longer controlling children or other offenders as it used to be in the early 1970s or as it is in the rural areas of Eastern Cape where sanctioning offenders is every community member's responsibility irrespective of the relationship between the community member and offenders. ${ }^{1}$

Individuals in Site B commit crimes or show intentions of committing crimes but residents take no action either reporting criminals to the police or sanctioning them. Everyone in the community works individually as was expressed by one of the participants who remarked that ...life in this township is about minding your own business. The traditional values of communalism, fraternity and collectiveness which are core features of social capital and ubuntu have been sacrificed in pursuit of individualism. ${ }^{2}$ The community lacks the rubric to be used as a tool to sanction offenders and hold offenders accountable. With this individualism it is very difficult for Site B residents to take initiative to prevent and fight criminal activities as Anleu (1998) points out that informal social controls flourish in the communities with little individualism, strong primary relationships, and where extended family retains primary authority.

In addition, a community keeps crime rates low if its members share common values and are willing to work on behalf of others (Sampson \& Groves, 1989; Brown, 2001). In the same vein, one prominent participant acknowledged that Site $\mathrm{B}$ and the whole Khayelitsha community experiences low level of communalism; and as a result, criminals tend to take advantages of this individuality. The participant commented that: ....in a divided community, criminals take advantages. Hence, some participants called all stakeholders to concentrate their efforts and resources so that they can fight crime collectively.

A number of participants stated that people tend to care for only their close family members, relatives and friends. They mentioned that if a person has no close relatives or friends no-one cares for him/her. They further exemplified that if a person is attacked by robbers; people pass or stand aside and watch the incident rather than assisting the victim. This individualism is an indication that Site B community experiences low quality of social capital and ubuntu which inculcate unconditional care for everyone. In a community that lives according to the dictates of ubuntu rescuing a person from danger does not necessarily require the need to know the person as ubuntu is centered on brotherhood, hospitality, and reciprocity (Nussbaum, 2003). Both social capital and ubuntu are key features of organised communities and they promote solidarity in controlling and preventing crime.

\subsection{Informal sanctions versus formal sanctions}

Data of this study shows that informal social controls conflict with formal sanctions rather than supporting and supplementing each other. It was stated that South African laws are used as a pretext why informal social sanctions are not exercised as deterrent tools. Some participants claimed that the laws strongly condemn the use of informal social sanctions such as corporal punishment as it is regarded as taking laws in their own hands. Discouraging citizens to sanction teenagers and other offenders informally may have negative impacts on crime situation in Site $B$ and the whole South Africa given that formal controls in the country are corrupt, weak and ineffective (Monagham, 2008; Faull, 2011).

Some studies reveal that formal sanctions deter criminal behaviours when work hand in hand with informal social sanctions (Fagan \& Meares, 2008; Jiang \& Lambert, 2009). The respondents raised a concern that the laws are too soft and protect criminals instead of punishing them. This makes some parents feel that their roles as parents are undermined. One parent expressed his disappointment saying that parents are no longer sanctioning their children because they may be accused for abusing their children while they were disciplining them.

One police officer insisted that allowing and encouraging people to exercise informal sanctions would endanger individuals' lives as residents are likely to take law into their own hands by requiting crime with crime. To show how

\footnotetext{
${ }^{1}$ The majority of Khayelitsha residents migrated from Eastern Cape Province where they were born and raised.

2 Literally, ubuntu is translated as collective brotherhood (personhood) and collective morality (Tshoose, 2009).
} 
serious the South Africa laws are against informal social sanctions, the police revealed that traditional courts referred to as 'buntu courts' in Khayelitsha were banned because their judgment was based on informal justice. In many cases criminal suspects are convicted without enough evidence. The police added that most sanctions offered by 'buntu courts' are corporal punishments and exceed the crime allegedly committed. Criminal suspects are sometimes killed if police do not intervene. The judges of these courts are normally community elders with little knowledge about laws and the legal system. Their judgment therefore, might be based on their personal feelings and views rather than law.

From a different perspective, it may be argued that 'buntu courts' and vigilantism would play a crucial role in reducing and preventing crime in the sense that the South African criminal system is allegedly ineffective (Singh, 2005; Faull, 2011). In line with this argument, some participants affirmed that there are incidents where residents have to punish criminal suspects before the police arrive otherwise the police would protect the suspects. In fact, the participants blamed police and laws for protecting and favouring criminals instead of punishing them. One participant described South African prisons as hotels claiming that criminals eat nice food and get the opportunity to make money while they are in prisons.

Besides the 'buntu courts', vigilantes are also accused of taking law in their own hands. Vigilantes are groups of few community members who are self-appointed to protect their areas against criminal activities including robbery and theft. This vigilantism approach, also known as 'street justice', metes out ruthless punishments. Killing criminal suspects using the 'necklace' (a burning tyre around the crime suspect's neck) is the most popular punishment used in vigilantism as echoed by a number of participants.

One participant emphasised that burning criminal suspects alive or killing them using other methods is the ultimate way of fighting crime in the community since the criminal justice system, including the South African Police Services (SAPS), failed to do their work. It was mentioned that, in the whole Khayelitsha community, at least three criminal suspects are being 'necklaced', killed using another method, or sjambokked, chased away from their families or from the community every month. Community members hold a belief that vigilantism would reduce criminal activities but vigilantism increases crime rates as it pays crime with crime, and it violates human rights and undermines the rule of law (Valji \& Harris, 2003).

\section{Conclusion}

Despite some vigilantism events taking place in Site B and elsewhere in Khayelitsha community, informal social controls are generally too weak to deter crimes and other deviant behaviours. Some residents are reluctant to prevent offenders from committing crime even if crimes are committed in their presence, the residents still take no action.

. Instead, the residents show unconcerned and stand aside watching crime happening as spectators or they continue their activities as expressed by some of the participants that they continue with their businesses if they see crime taking place. This lack of reactions to crime indicates high degree of individualism in Khayelitsha community. Crime cannot be prevented by few individuals rather by collective efforts and willingness of all community members especially parents given that most of the crimes are committed by teenagers and young adults who are still living with their parents.

In fact, a number of participants blamed parents for failing to take responsibility of controlling and guiding their children as parents. However, parents also blame the South African laws for not allowing parents to sanction their children. Blaming the South African laws for protecting offenders may be regarded as a pretext to both parents and other community members because some informal social sanctions such as condemnation, shame, and isolation are not criminalised in South Africa. Rather lack of solidarity and unity among residents of Khayelitsha community is the major reason why informal social controls are weak and hardly exercised by the residents.

Another root cause of the failure of informal social control is the reliance on formal controls which are administered by external agency (the criminal justice system). Citizens expect the criminal justice system especially police to control and prevent all criminal activities as the police is available everywhere all the time in the community controlling or monitoring criminals. There is nothing wrong for citizens to rely on the criminal justice system but the problem of this reliance is the ineffectiveness and inefficiency of some departments of the South African criminal justice system. The criminal justice system itself cannot fully combat the current high crime rates in Khayelitsha and other parts of the country. Hence, collaboration between the criminal justice and community members in fighting and preventing crime in the country is recommended. Future research can investigate the consequences of using informal social controls, such as buntu courts and vigilantes, as methods of crime prevention in Khayelitsha and other communities.

\section{References}

Anleu, S. L. R. (1998). The role of civil sanctions in social control: a socio-legal examination. Crime Prevention Studies, 9, 2-43. 
Benson, M. L. (1989). The influence of class position on the formal and informal sanctioning of white-collars offenders. The Sociological Quarterly, 30(3), 465-479.

Bishop, D. M. (1984). Legal and extralegal barriers to delinquency. Criminology, 22(3), 403-419.

Brewer, J. D., Lockhart, B. \& Rogers, P. (1998). Informal social control and crime management in Belfast. The British Journal of Sociology, 49(4), 570-585.

Brown, K. V. (2001). The determinants of crime in South Africa. The South African Journal of Economics, 69(2), 269-299.

City of Cape Town (2009). Khayelitsha urban upgrading programme launched. [Online] Available: http://www.capetown.gov.za len/Pages/Khayelitshaurbanupgradeproegrammelaunched.aspx (November 24, 2011).

De Wet, C. (2003). Eastern Cape educators' perceptions of the causes and the scope of school violence. Acta Criminologica, 16(3), 89106.

Dissel, A. (1997). Youth, street gangs and violence in South Africa. Centre for the Study of Violence and Reconciliation (CSVR). [Online] Available: http://www.csvr.org.za/wits/papers/papganga.htm (August 23, 2011).

Estelle, E. (2003). Poverty shocker for Cape townships. [Online] Available: http://www.101.co.za/news/south.africa/poverty-shocker-forcape-townships-1,1150710 (June 26, 2013).

Fagan, J., \& Meares, T. L. (2008). Punishment, deterrence and social control: the paradox of punishment in minority communities. Yale law School, Faculty Scholarship Series Paper 527. [Online] Available: http://moritzlaw.osu.edu/osjcl/Articles/Volume6_1?FaganMeares-PDF.pdf (May 23, 2011).

Faull, A. (2011). Corruption in the South African Police Service: civilian perceptions and experience. Institute for Security Studies (ISS), Paper 226. November 2011.

Flora, J. L. et al. (1997). Entrepreneurial social infrastructure and locally initiated economic development in the non metropolitan United States. The Sociological Quarterly, 38(4), 623-645.

Guarte, J. M., \& Barrios, E. B. (2006). Estimation under purposive sampling. Communications in Statistics Simulation and Computation, $35(2), 277-284$.

Jiang, S., \& Lambert, E. G. (2009). Views of formal and informal crime control and their correlates in China. International Criminal Justice Review, 19(1), 5-24.

Kawachi, I., Kennedy, B. P., \& Wilkinson, R. G. (1999). Crime: social disorganization and relative deprivation. Social Science and Medicine, 48(6), 719-731

Kornhauser, R. R. (1978). Social Sources of Delinquency. Chicago: University of Chicago Press.

Liebermann, S., \& Coulson, J. (2004). Participatory mapping for crime prevention in South Africa - local solutions to local problems. Environmental and Urbanisation, 16(2), 125-134.

Mampane, R., \& Bouwer, C. (2011). The influence of township schools on the resilience of their learners. South African Journal of Education, (31), 114-126.

Møller, V. (2005). Resilient or resigned? Criminal victimization and quality of life in South Africa. Social Indicators Research, 72(3), 263317.

Monagham, R. (2008). Community-based justice in Northern Ireland and South Africa. International Criminal Justice Review, 18(1), 83105.

Nleya, N., \& Thompson, L. (2009). Survey methodology in violence - prone Khayelitsha, Cape Town, South Africa. IDS (Institute of Development Studies) Bulletin, 40(3), 50-57.

Nussbaum, B. (2003). Ubuntu and business .... Reflections and questions. Perspectives, 17(3), 1-16.

Ostrom, E. (2000). 'Social capital: a Fat or Fundamental Concept?', in P. Dasgupta and I. Seragilden (Eds.), 'Social Capital: a Multifaceted perspective.' Washington DC: World Bank.

Palmary, I., \& Moat, C. (2002). Preventing criminality among young people. Centre for the Study of Violence and reconciliation (CSVR), December 2002. [Online] Available: http://www.csvr.org.za/docs/crime/preventingcriminality.pdf (March 12, 2012).

Pelser, E. (2008). Learning to be lost: youth crime in South Africa. Discussion Paper for the HSRC Youth Policy Initiative, Reserve Bank, Pretoria, 13 May 2008. Centre for Justice and Crime Prevention. [Online] Available: http://www.hsrc.ac.za/Document-2774.phtml (June 10, 2011).

Putnam, R. D. (2000). 'Bowling Alone: the Collapse and Revival of American Community.' New York: Simon \& Schuster.

Saegert, S., \& Winkel, G. (2004). Crime, social capital, and community participation. American Journal of Community Psychology, $34(3 / 4), 219-233$

Sampson, R. J., \& Groves, W. B. (1989). Community structure and crime: testing disorganisation theory. The American Journal of Sociology, 94(4), 774-802.

Schönteich, M. (1999). Assessing the crime fighters: the ability of the criminal justice system to solve and prosecute crime. Institute for Security Studies (ISS), Occasional Paper No. 40, September 1999. [Online] Available: http://www.iss.org.za/uploads/paper40.pdf (July 25, 2011).

Shaw, C.R., \& Mckay, H.D. (1942). Juvenile Delinquency and Urban Areas. Chicago: The University of Chicago Press.

Silver, E., \& Miller, L. L. (2004). Sources of informal social control in Chicago neighborhoods. Criminology, 42(3), 551-583.

Singh, D. (2005). Restoring to community justice when state policing fails: South Africa. Acta Criminologica, 18(3), 43-50.

Steyn, J., de Beer, M., \& Fouché, H. (2009). In anticipation of the 2010 Soccer World Cup in South Africa: occurrence of street robberies on Durban's "Golden Mile". Acta Criminologica, 23(3), 98-117. 
Tshoose, C. I. (2009). The emerging role of the constitutional value of ubuntu for informal social security in South Africa. African Journal of Legal Studies, 3(2), 12-19.

Valji, N., \& Harris, B. (2003). Vigilantes push us further from justice. [Online] Available: http://www.csvr.org.za/index.php/mediaarticles/latest-csvr-in-the-media/2316-vigilantes-push-us-further-from-justice.html (July 9, 2013).

Weijters, G., Scheepers, P., \& Gerris, J. (2009).City and/or neighbourhood determinants? Studying contextual effects on youth delinquency. European Journal of Criminology, 6(5), 439-555.Zimring, F. E. \& Hawkins, G. J. (1973). Deterrence: The Legal Threat in Crime Control. Chicago: University of Chicago Press. 
